\title{
With or Without EU? The Common Travel Area after Brexit
}

\author{
Sylvia de Mars and CRG Murray*
}

\section{Keywords}

Brexit - Common Travel Area - Freedom of Movement - UK/EU Withdrawal Agreement

\section{Abstract}

The Memorandum of Understanding (MoU) concluded between the UK and Ireland in May 2019 provides one of the few clear legacies of Theresa May's premiership. The Common Travel Area (CTA) between Ireland, the UK, the Channel Islands and the Isle of Man has long lacked legal definition. Nonetheless, for decades, it has provided the basis for domestic immigration and nationality laws which permit Irish citizens to reside in the UK and for them to be treated as 'not-foreign' in the context of UK domestic laws concerning access to healthcare, employment, social security, political participation and education. The UK and Ireland reciprocate, to a rough extent, these rights for each other's citizens. The MoU and related developments are first steps towards clarifying the CTA's scope. The manner in which this MoU was concluded, and the rush to alter parts of the UK's domestic law relating to the CTA, nonetheless speak to the fragile state of Ireland/UK relations after the Brexit referendum. This article explores whether these reforms will enable individuals reliant upon the CTA to protect their interests through litigation, and reflects upon the relationship between these arrangements and the settled-status rights proposed for EU citizens under the UK-EU Withdrawal Agreement.

\footnotetext{
* Senior Lecturer, Newcastle University (UK) and Reader, Newcastle University (UK). This research was supported by an Economic and Social Research Council Governance After Brexit Grant (ref. ES/S006214/1) and draws upon our contributions to a research briefing commissioned by the Joint Committee of the Irish Human Rights and Equality Commission and the Northern Ireland Human Rights Commission. Our thanks to Arabella Lang (House of Commons Library), Aoife O'Donoghue (Durham) and Ben Warwick (Birmingham) for their encouragement and comments upon earlier drafts of this article. Any errors remain our own.
} 


\section{Legacy Issues}

At the end of Theresa May's premiership, the Withdrawal Agreement ${ }^{1}$ she had concluded with the European Union (EU) slipped out of her grasp, in something akin to a "here's-whatyou-could-have-won" gameshow moment. Instead, some of her most significant achievements are the Common Travel Area (CTA) Memorandum of Understanding (MoU), signed in May 2019, ${ }^{2}$ and the Convention on Social Security, concluded a few months earlier. ${ }^{3}$ They were intended to supplement the Withdrawal Agreement, which specifically permits the UK and Ireland to continue their substantive CTA arrangements. ${ }^{4}$ Indeed, the MoU seemingly sat ready-to-action for months, awaiting the ratification of the overarching Withdrawal Agreement. ${ }^{5}$ As those months passed, the UK Government's commitments to preserving the 'special status' of UK and Irish citizens in each other's countries became less reassuring, especially given the precarity of May's position as Prime Minister. ${ }^{6}$ Her likely successor as Conservative leader, Boris Johnson, had already staked out his rejection of key provisions of the Withdrawal Agreement relating to Ireland, threatening an imminent deterioration of UKIreland relations.. The Irish Government therefore sought to lock down the new CTA arrangements independent of the Withdrawal Agreement, achieving this goal just two weeks before May announced her resignation.

This article evaluates whether the new agreements concluded between the UK and Ireland, and related domestic law, will transcend the inauspicious circumstances in which they were concluded by 'Brexit-proofing' the rights and entitlements associated with the CTA. This focus upon the new bilateral CTA arrangements leaves to one side the pervasive influence of

\footnotetext{
${ }^{1}$ Agreement on the Withdrawal of the United Kingdom of Great Britain and Northern Ireland from the European Union and the European Atomic Energy Community (25 November 2018).

2 Memorandum of Understanding between the Government of the United Kingdom of Great Britain and Northern Ireland and the Government of Ireland concerning the Common Travel Area and associated Reciprocal Rights and Privileges (8 May 2019). Available at: https://assets.publishing.service.gov.uk/government/uploads/system/uploads/attachment data/file/800280/ CTA-MoU-UK.pdf. Last accessed 30 June 2019.

${ }^{3}$ Convention on Social Security between the Government of the United Kingdom of Great Britain and Northern Ireland and the Government of Ireland, CP 49 (1 February 2019).

${ }^{4}$ Withdrawal Agreement, n 1, Ireland/Northern Ireland Protocol, Article 5.

${ }^{5}$ See D. Staunton, 'Deal Giving Reciprocal Rights for British, Irish citizens is Signed' Irish Times (8 May 2019).

${ }^{6}$ Department for Exiting the European Union, 'Common Travel Area Guidance' (22 February 2019) para.1. Available at: https://www.gov.uk/government/publications/common-travel-area-guidance/common-travelarea-guidance. Last accessed 30 June 2019.
} 
the UK-Ireland border upon the UK-EU Brexit negotiations. ${ }^{7}$ Although the issues are interlinked, the CTA arrangements warrant specific analysis, and our account unfolds in three phases. First, we examine how Brexit threatens the existing CTA arrangements. Second, we explore how the CTA is being recast in light of those pressures. Third, we assess whether the additional certainty provided by the new CTA measures will do much to protect the rights at stake or reset Irish-UK relations, and how the measures relate to the proposed settled-status arrangements for EU citizens within the UK-EU Withdrawal Agreement. Our analysis leads us to conclude that these developments fail to provide much of a consolation prize in terms of rights protections for those people reliant upon the CTA.

\section{The Operation of the CTA}

\section{Immigration Arrangements}

Having been hardly discussed for many years, at least in the UK, the CTA has become increasingly prominent within political discourse in the context of the Brexit debate. Brexit's leading proponents venerated the arrangements, with David Davis dismissing concerns over increasing regulation of the UK-Ireland land border after Brexit with the assertion that 'there was an open border before either of us was a member of the European Union, and we had the common travel area before we were members of the European Union' ${ }^{8}$ Little effort, however, was made to define the CTA or explain how it functioned in practice ahead of the Brexit referendum. ${ }^{9}$ Until Brexit, however, there was no urgency to determining the CTA's precise content, its legal status, or the extent to which it relies upon EU law. ${ }^{10}$ Arrangements upon which people moving between these jurisdictions base their day-to-day lives were thus shrouded in mystery.

\footnotetext{
${ }^{7}$ For general coverage, see T. Connelly, Brexit and Ireland: The Dangers, the Opportunities, and the Inside Story of the Irish Response (2nd ed, Penguin, 2018) and S. de Mars, C. Murray, A. O'Donoghue and B. Warwick, Bordering Two Unions: Northern Ireland and Brexit (Policy Press, 2018).

8 D. Davis, HC Deb., vol.614, col.54 (5 Sep 2016).

${ }^{9}$ A 'you-know-it-when-you-see-it' heuristic prevailed, reminiscent of Justice Potter Stewart's concurrence in Jacobellis v Ohio (1964) 378 US 184, 197.

${ }^{10}$ See M. Dougan, 'The "Brexit" Threat to the Northern Irish Border: Clarifying the Constitutional Framework', in M. Dougan (ed), The UK after Brexit: Legal and Policy Challenges (Intersentia, 2017) p.57, pp.60-68.
} 
If the border in Ireland is put into broader European context as part of 'the great wave of border creations after the First World War', ${ }^{11}$ the CTA which followed suit was an act of mitigation. It was conceived as an informal arrangement in 1923 which got both the UK and Irish Free State out of the troublesome task of immigration enforcement on the new border and, following wartime restrictions imposed in the 1940, it took on its modern form in 1952. It is one of the most extraordinary aspects of these arrangements that they have functioned effectively through these decades despite 'no international treaty of any kind establishing the $\mathrm{CTA}^{\prime}{ }^{12}$ Both the UK and Ireland have, at different times, emphasised that the arrangements are not a function of binding international law, but a policy maintained on the basis of national self-interest. In the 1950s, Irish policy makers were adamant that the CTA did not formally bind Ireland's ability to set its own immigration policy, underscoring Ireland's status as fully independent from the UK. ${ }^{13}$ Various UK Governments, moreover, have used the CTA's nonbinding nature to adjust the reciprocal rights on offer for Irish citizens in the UK, and even to unilaterally review the operation of the arrangements in 2008-2009. ${ }^{14}$

In practice, the CTA's significance for Ireland has often resulted in the Irish Government swiftly acting to align with new UK immigration policies. ${ }^{15}$ The introduction of the much-criticised 'direct provision' arrangements for asylum seekers in Ireland, for example, was explicitly justified on the basis that if Ireland operated a less restrictive policy than the UK, asylum seekers would be enticed to move through the UK to Ireland using the CTA. ${ }^{16}$ Ireland's courts, moreover, have upheld the refusal of a visa on the basis that an

\footnotetext{
11 J. Anderson and L. O'Dowd, 'Imperialism and Nationalism: The Home Rule Struggle and Border Creation in Ireland, 1885-1925' (2007) 26 Political Geography 934, 946.

${ }^{12}$ G. Butler and G. Barrett, 'Europe's 'Other' Open-Border Zone: The Common Travel Area under the Shadow of Brexit' (2018) 20 Cambridge Yearbook of European Legal Studies 252, 254. On the contrast with the Nordic Passport Union (Protocol of Copenhagen, 12 July 1957, 322 UNTS 245), also concluded in the 1950s, see P. LeinoSandberg and L. Leppävirta, 'Does Staying Together mean Playing Together?: The influence of EU Law on Cooperation between EU and Non-EU States: The Nordic Example' (2018) 43 ELR 295, 306-307.

${ }^{13}$ E. Meehan, Free Movement between Ireland and the UK: From the 'Common Travel Area' to the Common Travel Area (Policy Institute, 2000) p.22.

${ }^{14}$ See E. Fahey, 'Swimming in a Sea of Law: Reflections on Water Borders, Irish (-British)-Euro Relations and opting-out and opting-in after the Treaty of Lisbon' (2010) 47 CMLRev 673, 680-681.

${ }^{15}$ For an account of the importance Ireland attached to negotiating the CTA Protocol as part of the Treaty of Amsterdam, see B. McDonagh, Original Sin in a Brave New World: An Account of the Negotiation of the Treaty of Amsterdam (Institute of European Affairs, 1998) p.170

${ }^{16}$ See B. Ryan, 'The Common Travel Area between Britain and Ireland' (2001) 64 MLR 855, 873 and L. Thornton, 'A View from Outside the EU Reception Acquis: Reception Rights for Asylum Seekers in Ireland', in P. Minderhoud and K. Zwaan (eds), The Recast Reception Conditions Directive: Central Themes, Problem Issues, and Implementation in Selected Member States (Wolf Legal Publishers, 2016) p.49, pp.63-65.
} 
individual is seeking to use Ireland purely as a means to access the UK, thereby circumventing UK checks. ${ }^{17}$ Irish policy makers evidently want to be seen as maintaining the CTA's external face. ${ }^{18}$ This external face ensures that visa requirements still generally apply to nonEU/EEA/Swiss foreign nationals travelling between the CTA's constituent parts. ${ }^{19}$ The lists of third-countries whose citizens are required by Ireland and the UK to obtain entry visas are largely aligned, ${ }^{20}$ and the two countries share data on visa acceptances and refusals. ${ }^{21}$

The UK's Immigration Act 1971 provides what were, for some time, the only significant references to the CTA in UK law. ${ }^{22}$ The Act specified that travel into the UK from the Channel Islands, Isle of Man and the Republic of Ireland 'shall not be subject to control under this Act $^{\prime},{ }^{23}$ making exceptions for third-country citizens. ${ }^{24}$ In other words, the UK permitted entry of individuals from other parts of the CTA without border checks. ${ }^{25}$ Ireland long maintained equivalent arrangements, but from the 1990s introduced passport checks on air travellers, on the basis that this documentation was required for an individual to demonstrate their CTA travel entitlement. ${ }^{26}$ As we have seen, citizens of non-CTA members crossing the CTA's internal borders would still be legally required to possess any necessary permissions for entry, even if there was no specific monitoring of cross border travel for immigration purposes.

\footnotetext{
${ }^{17}$ Kweder v Minister for Justice [1996] 1 IR 381, 387 (Geoghegan J).

18 Aliens (Amendment) (No. 2) Order 1999 (SI 24/1999) (Ireland), article 5. Although the UK does not maintain comparable explicit measures for enforcing Irish rules, Ryan notes that the UK's immigration authorities could nonetheless be using more general powers to protect the CTA against abuse; see Ryan, n 16, p.865.

${ }^{19}$ See A. Shatter and D. Green, 'Joint Statement Regarding Co-operation on Measures to Secure the External Common Travel Area Border' (20 December 2011). Available at: http://www.inis.gov.ie/en/INIS/Pages/IRELANDUK\%20ACCORD\%20TO\%20FURTHER\%20SECURE\%20THE\%20COMMON\%20TRAVEL\%20AREA. Last accessed 30 June 2019.

${ }^{20}$ Ireland and the UK both impose visa requirements on 103 states, but the UK requires visas for citizens of six states where Ireland does not, and Ireland requires visas for citizens of seven states where the UK does not; HM Government, Northern Ireland and Ireland: Position Paper (2017) para. 22. Available at: https://assets.publishing.service.gov.uk/government/uploads/system/uploads/attachment data/file/638135/ 6.3703 DEXEU Northern Ireland and Ireland INTERACTIVE.pdf. Last accessed 30 June 2019.

${ }^{21}$ See Connelly, n 7, pp.242-243. For a detailed account of joint visa and visa waiver schemes, see Butler and Barrett, n 12, pp.274-277.

22 These arrangements provided the 'qualifying CTA entitlement' as an exception to the application of UK immigration law; British Nationality Act 1981 (UK), s.50A(5), as inserted into the legislation by the Borders, Citizenship and Immigration Act 2009 (UK), s.48(1).

${ }^{23}$ Immigration Act 1971 (UK), s.1(3).

24 ibid., s.9(2).

${ }^{25}$ D.W. Williams, 'British passports and the right to travel' (1974) 23 International \& Comparative Law Quarterly 642, 646.

${ }^{26}$ Aliens (Amendment) (No. 3) Order 1997 (SI 277/1997) (Ireland), Article 3. See also the Immigration Act 2004 (Ireland), s.4.
} 
These lasting arrangements illustrate the continuing significance of immigration rules within the CTA framework. However, Ireland and the UK have not stopped at facilitating travel; their special arrangements for each other's citizens extend far beyond creating a free-movement zone.

\section{Reciprocal Rights and Obligations}

The UK Government has repeatedly emphasised its ongoing commitment to the CTA after the 2016 Brexit referendum, identifying a range of reciprocal rights and entitlements for Irish citizens in the UK, and UK citizens in Ireland, as being derived from the CTA. These include the right to work without permit, the right to access education, the right to vote in local and parliamentary elections, and the ability to access to social welfare entitlements and benefits, health services and social housing. ${ }^{27}$ As we have seen, however, the CTA has not been set out in any comprehensive legal document, which calls into question how this account was assembled. ${ }^{28}$ By September 2017, the UK Government had mapped some 142 aspects of cross-border cooperation in Ireland and acknowledged that, of these, 96 were facilitated by EU law and 24 the CTA, information which was not made public until June $2019 .{ }^{29}$ The official narrative was increasingly conflating the free-movement zone with distinct issues relating to the rights and obligations of people using this zone. ${ }^{30}$

Irish citizens in the UK and the UK's citizens in Ireland are treated differently from other foreign nationals in each state's domestic law. In Ireland, individuals who are not Irish citizens are classed in law as 'non-nationals'. ${ }^{31}$ Over the decades, various statutory

\footnotetext{
${ }^{27}$ Department for Exiting the EU, 'Citizens' rights - UK and Irish Nationals in the Common Travel Area' (22 December 2017). Available at: https://www.gov.uk/government/publications/citizens-rights-uk-and-irishnationals-in-the-common-travel-area/citizens-rights-uk-and-irish-nationals-in-the-common-travel-area. Last accessed 30 June 2019.

${ }^{28}$ See Joint Committee on Human Rights, Legislative Scrutiny: Immigration and Social Security Co-ordination (EU Withdrawal) Bill (2019) HC 569/HL 324, para.20-21.

29 Department for Exiting the European Union, 'North-South Cooperation: Scoping Exercise' (13 September 2017). Available at: https://www.parliament.uk/documents/commons-committees/Exiting-the-EuropeanUnion/17-

19/Correspondence/1.\%20Draft\%20mapping\%20table,\%20sent\%20to\%20the\%20Commission\%20on\%2013\%2 OSeptember\%202017.pdf. Last accessed 30 June 2019.

${ }^{30}$ Seanad Special Committee on the Withdrawal of the United Kingdom from the European Union, Engagement on Citizenship Rights (8 May 2019) p.20 (Daniel Holder).

31 Immigration Act 1999 (Ireland), s.1(1). They had previously, in terminology inherited from UK law, been described as aliens; Aliens Act 1935 (Ireland).
} 
instruments have separated UK citizens out from this status. ${ }^{32}$ In the UK, the Ireland Act 1949 provides that Irish citizens are not to be treated as 'foreign for domestic law purposes. ${ }^{33}$ This language is, however, dated and open to interpretation. When modern UK immigration law details the rights of UK citizens by comparison to those of non-UK citizens the rights provided by a 'not-foreign' status are ambiguous. ${ }^{34}$ These immigration status provisions are supported by some specific laws which, whilst not mentioning the CTA, support broad equivalence of treatment between people from its constituent parts and home citizens. For example, electoral law in both Ireland and the UK makes explicit provision for voting rights for each other's citizens in parliamentary elections. ${ }^{35}$ Such reciprocity is rarely exact; in considering the impact of Ireland and the UK's opt-out from Schengen on the application of EU law, the UK Supreme Court affirmed that 'it would be going too far to insist on a precise match between the arrangements on one side of the Irish Sea and the other'.$^{36}$

Neither the UK nor Ireland guarantees that the other's citizens will continue to be treated in a manner which is in most respects equivalent as its own citizens. Instead, both effectively maintain a separate category in nationality and immigration law for the other's citizens. This category is conditioned by an understanding that each state will treat the other's citizens as roughly equivalent to home citizens. The UK Government's catalogue of reciprocal rights therefore follows from the Ireland Act 1949's recognition that Irish citizens are not foreign. Specific manifestations of this principle are, however, scattered across disparate areas of domestic law and policy. For instance, conditions for accessing public healthcare or benefits once resident in the other jurisdiction are a matter of domestic healthcare law, while admissions policies for publicly-funded primary and secondary education are found in domestic education law. ${ }^{37}$ In practice, then, these rights persist only for as long as the UK and Ireland's legislatures accept them.

\footnotetext{
32 See, most recently, the Aliens (Exemption) Order 1999 (SI 97/1999) (Ireland).

33 Ireland Act 1949 (UK), s.2(1).

${ }^{34}$ See S. Cox, Brexit and Irish citizens in the UK: How to Safeguard the Rights of Irish Citizens in an Uncertain Future (Traveller Movement, 2017) p.10. Available at: https://travellermovement.org.uk/wpcontent/uploads/2018/08/TTM-Brexit and Irish citizens in the UK web.pdf. Last accessed 30 June 2019.

${ }^{35}$ See the Electoral (Amendment) Act 1985 (Ireland), s.2 and the Representation of the People Act 1983 (UK), s.1.

${ }^{36}$ Patmalniece v Secretary of State for Work and Pensions [2011] UKSC 11; [2011] 1 WLR 783, [60] (Lord Hope).

${ }^{37}$ Irish nationals in the UK hold rights under the NHS Act 2006 (UK) and the Education Act 1996 (UK). UK nationals in Ireland hold rights under the Health Act 1970 (Ireland) and the Education Act 1988 (Ireland) and the Education (Admissions to Schools) Act 2018 (Ireland). See S. de Mars, C. Murray, A. O'Donoghue and B. Warwick, Discussion
} 


\section{UK-Ireland Arrangements and EU Law}

Brexit has therefore exposed significant shortcomings inherent in the CTA's historical informality. Most of what the UK Government calls CTA 'rights' rest on no firmer legal basis than aging domestic legislation in the UK and Ireland which uses dated language. At a more fundamental level, upon Brexit the land border between the UK and Ireland will become a frontier of the EU. The continuation of the CTA after Brexit therefore required negotiations and compromises between the UK, Ireland and the EU. For the UK, individuals who are not citizens of the CTA members could take advantage of the absence of passport or visa checks at this land border. The resultant "backdoor" is difficult to square with the Brexit narrative of 'taking back control' of immigration. ${ }^{38}$ For the EU, by contrast, the exceptions to EU border controls which it had made for Ireland and the UK when both were Member States to enable them to maintain the $\mathrm{CTA}^{39}$ become harder to sustain in the context of Brexit. ${ }^{40}$ And although the CTA predated Ireland's EU membership, Ireland will have to fulfil EU law obligations after Brexit which did not affect the operation of the CTA before $1974 .{ }^{41}$

The mutual benefits in maintaining the CTA, alleviating the burden of administering the land border and improving population flows across the Atlantic Islands, have sustained these arrangements for a century. ${ }^{42}$ It is a relationship built on trust and a certain measure of tolerance by the EU. There is, however, no obvious legal avenue if trust breaks down, or slowly erodes, in the context of Brexit. The Chief Constable of the Police Service of Northern Ireland (PSNI), for example, has complained to the UK Parliament that shortcomings in Ireland's immigration enforcement in recent years have contributed to a spike in immigration offences within Northern Ireland. ${ }^{43}$ Although this lobbying ultimately yielded more extensive

\footnotetext{
Paper on the Common Travel Area (Joint Committee of the Irish Human Rights and Equality Commission and the Northern Ireland Human Rights Commission, 2018) pp.32-34 and pp.63-65.

${ }^{38}$ Connelly, n 7, p.244. See also J. Doyle and E. Connolly, 'Brexit and the Northern Ireland Question' in F. Fabbrini (ed.), The Law \& Politics of Brexit (OUP, 2017) p.139, pp.150-151.

${ }^{39}$ Treaty on the Functioning of the European Union (TFEU), Protocol 20 on the application of certain aspects of Article 26 of the Treaty on the Functioning of the European Union to the United Kingdom and to Ireland.

${ }^{40}$ For pressure on the special arrangements predating moves towards Brexit, see P.J. Kuijper, 'The Evolution of the Third Pillar from Maastricht to the European Constitution: Institutional Aspects' (2004) 41 CML Rev 609, 621623.

${ }^{41}$ See D. Schiek, 'Brexit on the Island of Ireland: Beyond Unique Circumstances' (2018) 69 Northern Ireland Legal Quarterly 367, 384-385 and Dougan, n 10, pp.67-68.

42 See Ryan, n 16, p.874.

${ }^{43}$ G. Hamilton, 'Evidence to Northern Ireland Affairs Committee' (13 December 2016) HC 700, Q165.
} 
immigration enforcement powers for the PSNI along the land border, ${ }^{44}$ the episode evidenced how tensions over border enforcement could escalate after Brexit. Against this backdrop, the House of Lords' EU Committee warned that 'both Governments need to take action to convince EU colleagues of its (the CTA's) necessity, in particular in the context of the unique circumstances in Northern Ireland'. ${ }^{45}$ As we will discuss below, these efforts culminated in the Withdrawal Agreement's provisions sustaining the CTA. ${ }^{46}$

Notwithstanding the EU's agreement that the CTA can continue, ensuring its operation post-Brexit will not be straight-forward. One particular difficulty is the degree to which EU law currently sustains elements of the CTA that could otherwise be set aside as a matter of domestic law and policy. When the CTA was instituted, state welfare provision was limited and Irish and UK citizens continued to share the overarching status of British subjects. ${ }^{47}$ There was therefore no need for legalised arrangements for reciprocal access to welfare provisions until the late 1940s, when welfare provision expanded, Ireland left the Commonwealth and the UK reformed its nationality law. ${ }^{48}$ Legislation at this juncture in Ireland and the UK affirmed reciprocal treatment of each other's citizens, but these measures were not couched in terms of legal rights against discriminatory treatment on the basis of nationality. In Ireland, the relevant statutory instrument contained a particularly vague assurance that UK citizens 'enjoy in Ireland similar rights and privileges to those enjoyed by Irish citizens in the United Kingdom and Colonies' ${ }^{49}$ The UK's Ireland Act 1949, moreover, has not played a prominent part in the litigation initiated to protect the legal interests of Irish citizens resident in the UK. In the rare cases in which it has been invoked, such as Re $O^{\prime}$ Conor's Application, $^{50}$ it has not had a meaningful impact. In this case Girvan J responded to claims that, under the terms of the 1949 legislation, Irish citizens are not foreign, by emphasising that 'neither are they British

\footnotetext{
${ }^{44}$ Counter-Terrorism and Border Security Act 2019 (UK), Sch.3, para.2-6.

${ }^{45}$ European Union Committee, Brexit: UK-Irish Relations (12 December 2016) HL Paper 76, para.114.

${ }^{46}$ Withdrawal Agreement, n 1, Ireland/Northern Ireland Protocol, Article 5.

47 What Barnard and Ludlow flag as the 'notion of "undeserving" migrant' accessing UK public services was yet to exert the grip over public consciousness which it would achieve from the latter part of the twentieth century; C. Barnard and A. Ludlow, “Undeserving” EU Migrants "Milking Britain's Benefits"? EU Citizens before Social Security Tribunals' [2019] PL 260, 279.

${ }^{48}$ Irish citizens could apply to become UK citizens under the British Nationality Act 1948 (UK), s.2(1).

${ }^{49}$ Citizens of the United Kingdom and Colonies (Irish Citizenship Rights) Order 1949 (SI 1/1949) (Ireland), Article 2 (emphasis added).

${ }^{50} \mathrm{See}$, for example, Re O'Conor's Application [2005] NIQB 11.
} 
citizens' ${ }^{51}$ Instead they fell into an intermediate category, in which it was up to the courts to determine whether differentiated treatment was acceptable. As a result, the rights seemingly assured by the CTA can sometimes be threatened by proposals which take little account of the special nature of the CTA arrangements. For example, the Goldsmith Report into UK citizenship, commissioned by Gordon Brown's Labour Government, advocated removing Irish citizens from the UK parliamentary franchise as a supposed means of bolstering the connection between UK citizens and the UK legislature. ${ }^{52}$ The CTA, it would appear, is all too readily overlooked within UK policy making.

Only after Ireland and the UK joined the European Economic Community (EEC) in 1974 did Irish citizens in the UK and UK citizens in Ireland gain an effective framework through which to mount legal challenges against applications of domestic law which discriminated against them as foreign nationals. Free movement rights proved harder to circumvent than the CTA's vague arrangements. In 1974, following the Birmingham and Guilford bombings by the Provisional Irish Republican Army, the UK Prime Minister Harold Wilson ordered contingency planning for imposing travel restrictions on Irish citizens travelling into Great Britain. Officials agonised that travel controls would cause 'resentment', and could therefore exacerbate the threat of terrorist attacks in Great Britain. ${ }^{53}$ They also identified a vital legal impediment; whilst European Convention on Human Rights obligations could be subject to derogation, ${ }^{54}$ there was no such means to block an EEC Commission enforcement action bringing the UK before the Court of Justice 'on the grounds that it was failing to meet its obligations under the Treaty'. ${ }^{55}$

Individuals began to rely upon these rights in litigation. In $\operatorname{Singh}^{56}{ }^{5}$ the Court of Justice recognised that UK nationals could, by setting up residence in another Member State (including Ireland), activate their EU law rights and circumvent UK restrictions on the residency of spouses who are third country nationals. The development of EU citizenship after

\footnotetext{
51 ibid., [5].

52 P. Goldsmith, Citizenship: Our Common Bond (HMSO, 2008) pp.75-76. Available at: http://image.guardian.co.uk/sys-files/Politics/documents/2008/03/11/citizenship-report-full.pdf. accessed 30 June 2019.

53 UK National Archives File FCO 50/549 ‘Group on Entry Control: Report’ (16 December 1975) para. 8.3.3.

54 ibid., para. 7.5.1.

55 ibid., para. 7.4.1.

${ }^{56}$ Case C-370/90 R v Immigration Appeals Tribunal and Surinder Singh, ex p Secretary of State for the Home Department [1992] ECR I-1.
} 
the Maastricht Treaty reinforced this trend. ${ }^{57}$ In Zhu and Chen, ${ }^{58}$ the CTA offered little protection for a Chinese citizen and her child, who had Irish citizenship by virtue of her birth in Belfast, against UK Home Office officials' refusal to grant residence permits. The Court of Justice decided that the child, for as long as she had sickness insurance and was not a burden on the public finances of the UK as host State, enjoyed 'a right to reside for an indefinite period in that State'. ${ }^{59}$ Furthermore, these EU law rules also 'allow a parent who is that minor's primary carer to reside with the child in the host Member State' ${ }^{60} \mathrm{~A}$ decade later, in McCarthy, ${ }^{61}$ the Court confirmed that the UK and Ireland's opt out from the Schengen free movement area 'does not permit the United Kingdom to determine the conditions for entry of persons who have a right of entry under EU law' ${ }^{62}$ These cases contributed to a narrative in the UK that the Court of Justice was enabling individuals to abuse the rights available to them under the CTA and EU law. ${ }^{63}$ In reality, however, but for the Court's oversight, these the supposed rights connected to freedom of movement would have conferred no actual benefits upon individuals.

EEC membership also necessitated extensive reforms to protectionist labour market practices which had persisted, in both the UK and Ireland, in spite of the CTA. ${ }^{64}$ The vestiges of such practices were broken down only through litigation before the Court of Justice. For example, despite the operation of the CTA, provisions in Northern Ireland's child benefit law which disadvantaged some cross-border workers persisted into the 1990s. In these circumstances, the role played by EU law in reinforcing the CTA was vital. In McMenamin, ${ }^{65}$ the claimant was not paid the full rate of child benefit which would ordinarily apply as a result of her employment in Northern Ireland because she and her children were resident in Ireland.

\footnotetext{
${ }^{57}$ Treaty on the Functioning of the European Union, Articles 20, 21 and 26 and Directive 2004/38/EC of the European Parliament and of the Council on the right of citizens of the Union and their family members to move and reside freely within the territory of the Member States, OJ L 158 (30 April 2004), p. 77. See S. Reynolds, 'May We Stay? Assessing the Security of Residence for EU Citizens Living in the UK' in M. Dougan, The UK after Brexit: Legal and Policy Challenges (Intersentia, 2017) p.181, pp.196-198.

${ }^{58}$ C-200/02 Zhu and Chen v Secretary of State for the Home Department [2004] ECR I-9925.

59 ibid, para. 41 .

60 ibid, para.46.

${ }^{61}$ Case C-202/13 R (McCarthy) v Secretary of State for the Home Department [2014] EU:C:2014:2450.

62 ibid, para.64.

${ }^{63}$ See C. Vincenzi, 'European Citizenship and Free Movement Rights in the United Kingdom' [1995] PL 259, 267269 and P. Brazil and C. Cosgrave, 'The Implications of Brexit for British Citizens in Ireland Navigating the Irish Immigration System' (2018) 32 JIANL 10, 15.

${ }^{64}$ See S. de Mars, et al., n 37, pp.27-28.

${ }^{65}$ Case C-119-91 McMenamin v Adjudication Officer [1992] ECR 1-6393.
} 
The Court of Justice ruled that in these circumstances the UK was obliged to top up any payments by Ireland to ensure that the claimant received a level of child benefit equivalent to that of her colleagues resident in Northern Ireland. ${ }^{66}$ Cases like this built up the detailed provisions coordinating social security under EU law. ${ }^{67}$ Gráinne McKeever emphasises the value of this body of EU law in the CTA context in harmonising 'hugely complex tax systems' and mapping them to 'the complexity of individual lives' ${ }^{68}$ EU rights of access to services ${ }^{69}$ also enabled a parent from Northern Ireland to challenge HM Revenue \& Customs' decision that she had not been entitled to tax credits on the basis that she had used a childcare provider which the scheme did not support because it was based in the Republic of Ireland. ${ }^{70}$

The tendrils of EU law therefore stretch deep into the existing cross-border arrangements between the UK and Ireland. ${ }^{71}$ People circulating between these countries under the CTA rely upon this framework of rules to conduct their lives. Figures recently released to Dáil Éireann revealed that social security coordination on pensions alone covered some 132,000 people living in Ireland in receipt of UK state pensions, and that 28,760 people living in the UK received some state pension contribution from Ireland. ${ }^{72}$ Brexit, however, promises to end the UK's obligations to EU citizens, including Irish citizens, which derive from EU law. UK citizens in Ireland, moreover, will 'no longer enjoy the same level of rights and safeguards as currently provided by EU law'. ${ }^{73}$ Without the support of EU law's binding obligations, the rights and entitlements hitherto extended by Ireland and the UK to each other's citizens appear increasingly vulnerable to the shifting sands of Brexit politics.

\section{The CTA and the People of Northern Ireland}

\footnotetext{
66 ibid, para. 27.

67 See Regulation 883/2004/EC of the European Parliament and of the Council of 29 April 2004 on the coordination of social security systems, OJ L 166 (30 April 2004), p.1, and Regulation 987/2009/EC of the European Parliament and of the Council of 16 September 2009 laying down the procedure for implementing Regulation 883/2004, OJ L 284 (30 October 2009), p.1.

68 G. McKeever, 'Brexit, the Irish Border and Social Security Rights' (2018) 25 JSSL 34, 48.

69 TFEU, Article 56 and Directive 2006/123/EC of the European Parliament and of the Council of 12 December 2006 on services in the internal market.

${ }^{70}$ NB v HMRC [2016] NICom 47, para.105. HM Revenue \& Customs withdrew their planned appeal against this decision in late 2018. For more information, see McKeever, n 68, pp.49-55.

${ }^{71}$ For coverage across sectors, see S. de Mars, et al., n 37, pp.31-82.

72 R. Doherty, TD, Select Committee on Employment Affairs and Social Protection (21 February 2019) p.2. Available at: https://www.welfare.ie/en/pressoffice/pdf/sp210219a.pdf. Last accessed 30 June 2019.

${ }^{73}$ See Brazil and Cosgrove, n 63, p.26.
} 
The UK's withdrawal from the EU membership brings with it a further Northern Irelandspecific complication to the CTA arrangements. Ireland has, since the 1950s, made explicit statutory provision enabling people born in Northern Ireland to claim Irish citizenship. ${ }^{74}$ Following the 2004 citizenship referendum, this right was restricted to children born in Northern Ireland with at least one parent who was an Irish or UK citizen. ${ }^{75}$ These changes were, in part, a response to cases such as Chen and Zhu, and the pressures which the Irish Government argued they were putting on the CTA. ${ }^{76}$ Notwithstanding this amendment, most people born in Northern Ireland remain automatically entitled to both UK and Irish citizenship. Indeed, the Belfast/Good Friday Agreement (GFA) acknowledges the 'birthright' of the people of Northern Ireland to identify as either British, or Irish, or both. ${ }^{77}$

This birthright creates a distinct body of Irish citizens living within the UK whose rights derive from the GFA and not from the CTA. But although they are therefore EU citizens, as such individuals born in the UK have not moved to another EU Member State, they will find it difficult to assert that they have activated some of their EU citizenship rights. ${ }^{78}$ The UK Government moreover insists, drawing upon the definition of a UK citizen in British Nationality Act $1981,^{79}$ that they are prima facie also UK citizens. This position is being contested in the ongoing DeSouza litigation, in which a Northern Ireland-born woman who identifies as Irish seeks to rely on her EU citizenship to secure the residency of her spouse, a third-country national. The Home Office is contesting this litigation on the basis that to claim EU citizenship rights relating to third-country national spouses, the claimant would first need to renounce her UK citizenship, a status which she does not recognise. ${ }^{80}$ Some measures, such

\footnotetext{
${ }^{74}$ Irish Nationality and Citizenship Act 1956 (Ireland), s.6(a). Previously Irish law had extended citizenship by descent, which had covered many people born in Northern Ireland if their families had lived there prior to partition; B. Ryan, 'The Ian Paisley Question: Irish Citizenship and Northern Ireland' (2003) 25 Dublin University Law Journal 145, 152-155.

75 Irish Nationality and Citizenship Act 2004 (Ireland), s.3(d).

${ }^{76}$ See B. Ryan, 'The Celtic Cubs: The Controversy over Birthright Citizenship in Ireland' (2004) 6 European Journal of Migration and Law 173, 186-188.

77 Agreement between the Government of the United Kingdom of Great Britain and Northern Ireland and the Government of Ireland (with annexes) 10 April 1998, 2114 UNTS 473, Constitutional Issues, Article 1(vi).

78 See McCarthy, n 61, [36] and C-127/08 Metock v Minister for Justice, Equality and Law Reform [2008] EU:C:2008:449, [73].

${ }^{79}$ British Nationality Act 1981 (UK), s.1.

80 ibid., s.7. For coverage of the state of proceedings at the time of writing, see L. O'Carroll, 'Derry woman's USborn husband free to live in UK, court rules' The Guardian (12 Feb 2018).
} 
as the UK Civil Service Nationality Rules, ${ }^{81}$ already divide Irish citizens based upon whether or not they form part of the people of Northern Ireland. ${ }^{82}$

Regardless of the outcome of the DeSouza litigation, the UK authorities are preparing for Brexit on the basis that different categories of Irish citizen exist. So too, it must be noted, are the Irish authorities, given the public announcement that they will underwrite the cost of the continued provision of European Health Insurance Cards for the people of Northern Ireland, but not for Irish residents of Great Britain, in the event of a no-deal Brexit. ${ }^{83}$ The imperative for the UK Government must nonetheless remain to provide for broadly similar rights and entitlements to both groups. Failure to do so will generate not only the administrative burdens of separating Irish citizens into either group dependent upon the rights and entitlements at issue, but also inevitable legal challenges drawing upon the postGFA protections for equality of treatment. ${ }^{84}$

\section{The CTA and Brexit Negotiations}

For as long as Ireland and the UK have been part of the EU and its forerunners, the CTA has committed both countries to treating each other's citizens more favourably than the citizens of other EU Member States, providing a level of equivalence to home citizens which EU law does not require. The UK therefore entered withdrawal negotiations with the EU braced for confrontation over the CTA's retention. ${ }^{85}$ Ireland, however, had worked assiduously to win the EU Commission around to the importance of the CTA, and its retention became an uncontroversial element of the December 2017 Joint Report on the UK-EU withdrawal

\footnotetext{
81 Civil Service Nationality Rules (2007) (UK), para.1.16. Available at: https://assets.publishing.service.gov.uk/government/uploads/system/uploads/attachment data/file/536134/ civil servicenationality rules 20 june 2016.pdf. Last accessed 30 June 2019.

82 These exclusions have been upheld by the Northern Ireland courts; see Re O'Boyle's Application (2000) 4 Eur L Rep 637.

83 L. Varadkar, TD, Dáil Debates, vol.265, speech 4 (8 May 2019).

${ }^{84}$ Incorporated into domestic law as protections on discrimination on grounds of political opinion under the Northern Ireland Act 1998, s.6 and ss.75-76. See C. McCrudden, 'Equality and the Good Friday Agreement', in J. Ruane and J. Todd (eds), After the Good Friday Agreement: Analysing Political Change in Northern Ireland (UCD Press, 1999) p.97.

${ }^{85}$ Connelly, n 7, pp.327-328.
} 
negotiations ${ }^{86}$ and ultimately the ill-fated Withdrawal Agreement. ${ }^{87}$ In keeping with the existing arrangements under Protocol 20 to the Treaty on European Union (TEU), Article 5 of the Ireland/Northern Ireland Protocol would allow for the continued existence of the CTA, but does not set out how the CTA will operate, nor does it clarify the legal regimes (whether domestic or EU-law in origin) which will underpin the ongoing operation of the CTA. It provides for a potential sting in the tail, in that it only authorises the CTA's continuation insofar as it does not conflict with Ireland's EU obligations. At the very least this will mean that Ireland cannot match any freedom of movement restrictions placed upon the citizens of other EU/EEA Member States imposed by the UK after Brexit. Some commentators have suggested that such provisions could see the Court of Justice examining whether Ireland's application of EU-equivalent social security rules to UK citizens moving to Ireland advantage them over any EU citizens who move from the UK into Ireland. ${ }^{88}$ As such, the Brexit negotiations produced at best a continuing tolerance of the CTA, but no specific means by which to ensure that the rights that are associated with the CTA could continue to be exercised.

Irish citizens resident in the UK have nonetheless been assured by the UK Government that they need not concern themselves with the settled-status scheme being developed for EU citizens resident in the UK. The UK's Immigration Minister, Caroline Noakes, used a prominent article in the Belfast Telegraph to assert that 'Irish citizens will not need to apply to the EU Settlement Scheme' ${ }^{89}$ This statement risks being disingenuous. It masks the fact that one group of Irish citizens in the UK, those who belong to the people of Northern Ireland, were excluded from the operation of the scheme on the premise that they were British within the terms of the British Nationality Act $1981 .{ }^{90}$ For the other group of Irish citizens resident in the UK, the Minister's assurance is premised upon the rights they retain as a result of the

\footnotetext{
${ }^{86}$ Negotiators of the EU and UK Government, Joint Report from the Negotiators of the European Union and the United Kingdom Government on progress during phase 1 of negotiations under Article 50 TEU on the United Kingdom's orderly withdrawal from the EU (8 December 2017) para.54.

${ }^{87}$ Withdrawal Agreement, n 1, Ireland/Northern Ireland Protocol, Article 5.

${ }^{88}$ See Reynolds, $n 57$, p.198. Such a challenge to the UK's pension arrangements was rejected by the UK Supreme Court in Patmalniece, $\mathrm{n} 36$, as being indirectly discriminatory but justified on the basis of nationality, but this was against the backdrop of both Ireland and the UK being EU Member States.

${ }^{89}$ C. Noakes, 'Settlement Scheme will help reassure 60,000 EU citizens living in Northern Ireland' Belfast Telegraph (30 March 2019).

${ }^{90}$ See C. Noakes, MP, HC Written Question 213222 (5 February 2019).
} 
CTA's operation..$^{91}$ As there are no CTA arrangements which are binding upon the UK, however, these rights could be varied at will by future UK legislation. The settled status assured by the Withdrawal Agreement, by contrast, held out enforceable rights secured by the oversight, in the first eight years after Brexit, by facility for reference to the Court of Justice, ${ }^{92}$ and also by an Independent Monitoring Authority. ${ }^{93}$ The Withdrawal Agreement also provided for the continued enjoyment of specific EU citizenship rights, such as the ability of immediate third-country national family members to reside in the UK under EU freedom of movement rights. These rights are notably more generous than those of UK citizens, who must pass strict income tests if third-country spouses are to be granted UK residence, and are not thereby protected under the CTA. ${ }^{94}$ As the Immigration Minister informed the UK Parliament;

Under the settlement scheme in a deal scenario, close family members who are not already resident in the UK will be able to join an EU citizen - that includes Irish citizensunder the same conditions as now, where the relationship pre-existed the end of the implementation period. ${ }^{95}$

With the Withdrawal Agreement thrown into doubt the air by Theresa May's inability to secure its ratification by the UK Parliament, her Government has unilaterally asserted that it will nonetheless offer settled status to EU citizens already resident in the UK, meaning that these EU-originating rights might continue to underpin the status of those Irish citizens resident in the UK before a future 'exit day' if they take up the scheme. ${ }^{96}$ Irish citizens who move to the UK after Brexit, on the other hand, will be reliant upon the CTA for their rights and obligations. If their future rights and obligations are built on limited foundations, then

\footnotetext{
91 UK Home Office, EU Settlement Scheme: Statement of Intent (21 June 2018) para.2.6. Available at: https://assets.publishing.service.gov.uk/government/uploads/system/uploads/attachment data/file/718237/ EU Settlement Scheme SOI June 2018.pdf. Last accessed 30 June 2019.

92 Withdrawal Agreement, n 1, Article 158.

93 ibid., Article 159.

${ }^{94}$ See JCHR, n 28, para.19.

95 Public Bill Committee, Immigration and Social Security Coordination (EU Withdrawal) Bill (Fifth sitting) (26 February 2019) col.174 (Caroline Noakes, MP).

${ }^{96}$ Home Office, 'Policy Paper: Immigration from 31 October 2019 if there is no deal' (28 January 2019). Available at: $\quad$ https://www.gov.uk/government/publications/eu-immigration-after-free-movement-ends-if-theres-nodeal/immigration-from-30-march-2019-if-there-is-no-deal. Last accessed 30 June 2019.
} 
the same can be said of UK citizens in Ireland. Moreover, the inability of the UK Government to ratify the Withdrawal Agreement also threw into doubt its carefully assembled transitional arrangements for social security coordination. ${ }^{97}$ These factors combined to push reform of the CTA to the forefront of the political agenda.

\section{Reforming the CTA}

As discussed above, the CTA has, historically, amounted to a set of practices rather than a binding guarantee that Irish citizens will continue to enjoy equivalent rights to home citizens in the UK, and vice versa. At present, by contrast, EU membership commits Ireland and the UK to providing for EU citizenship rights. Insofar as overlaps exist between these regimes, EU law currently injects protections against discrimination on the basis of nationality into much of the CTA's practical application. Upon Brexit, however, those EU obligations fall away. At this point, goodwill regarding the CTA arrangements cannot be equated to binding obligations upon Ireland and the UK not to discriminate against citizens from other parts of the CTA. Efforts to Brexit-proof CTA arrangements have therefore begun in earnest, through domestic legislation and bilateral agreements between the UK and Ireland.

\section{UK Domestic Law}

Brexit, it is by now trite to say, necessitates a major overhaul of the UK statute book. ${ }^{98}$ Part of this effort updates aspects of the domestic legal provisions relating to Irish citizens and their status in the UK. The European Union (Withdrawal) Act 2018 establishes a default rule whereby EU law and related UK measures are retained after Brexit, with fresh legislation being required to move away from this position. ${ }^{99}$ One vital piece of legislation, the Immigration and Social Security Co-ordination (EU Withdrawal) Bill, remains stuck in the House of Commons because of the saga over ratification of the Withdrawal Agreement. This legislation will nonetheless have to be passed before Brexit, if the UK is to the end EU citizens' freedom of movement into the UK. ${ }^{100}$

\footnotetext{
${ }^{97}$ Withdrawal Agreement, n 1, Article 31.

98 K.A. Armstrong, Brexit Time: Leaving the EU - Why, How and When? (CUP, 2017) pp.182-183.

${ }^{99}$ European Union (Withdrawal) Act 2018 (UK), ss.2-4.

${ }^{100}$ Immigration and Social Security Co-ordination (EU Withdrawal) Bill 2019 (UK), cl.1 and sch.1.
} 
Against this backdrop of the Bill's provisions curtailing freedom of movement, specific saving provisions are made with regard to Irish citizens, clarifying how they are to be treated for immigration purposes after Brexit. At present, the Immigration Act 1971 only formally applies exemptions from immigration control for Irish citizens making 'local' journeys, meaning those between the constituent parts of the CTA. ${ }^{101}$ This provides for a poor fit with contemporary international travel, and EU free movement law produced a situation whereby these statutory point-of-departure rules became inoperative. ${ }^{102}$ As soon as the UK sought to restrict freedom of movement, it therefore also became necessary to amend the 1971 Act to clarify that Irish citizens do not require 'leave to enter or remain in the UK' as a general rule. ${ }^{103}$

The proposals furthermore clarify the exceptions to free movement into the UK for Irish citizens, in the form of deportation orders, public good exclusions and international law exclusions. ${ }^{104}$ Deportation of Irish citizens has been possible under UK immigration law since 1962. ${ }^{105}$ Under the Immigration Act 1971, a narrow class of Irish citizens was exempted from deportation from the UK, establishing that all others are subject to deportation. ${ }^{106}$ Irish citizens currently enjoy protections under EU free movement law, which explicitly sets a high threshold for a host Member State to deport an EU citizen to their home country. ${ }^{107}$ An EU citizen must be a current threat to public security or policy in order to be deportable, and deportation decisions must take account of the duration of residency in the host State. ${ }^{108}$ The new Bill, as drafted, provided no explicit threshold for deportation of Irish citizens, seemingly preserving the existing policy, contained within a ministerial statement, whereby 'Irish citizens will only be considered for deportation where a court has recommended deportation in sentencing or where the Secretary of State concludes ... the public interest requires

\footnotetext{
101 Immigration Act 1971 (UK), s.1(3).

102 See the Immigration (European Economic Area) Regulations 2016 (SI 2016/1052) (UK), Regulation 2(1) (which cover Ireland in the application of EU free movement law as an EU Member State). See also Public Bill Committee, Immigration and Social Security Coordination (EU Withdrawal) Bill (Fifth sitting) (26 February 2019) col.174 (Caroline Noakes, MP).

103 Immigration and Social Security Co-ordination (EU Withdrawal) Bill 2019 (UK), cl.2(1).

104 ibid., cl.2(2)-(3).

${ }^{105}$ Commonwealth Immigrants Act 1962 (UK), s.6(3).

106 Immigration Act 1971 (UK), s.7(1)(b).

107 Directive 2004/38/EC, n 57, Articles 27-28 and The Immigration (European Economic Area) Regulations 2016 (SI 2016/1052) (UK), Reg. 27(5).

108 See Secretary of State for the Home Department v Dumliauskas [2015] EWCA Civ 145; [2015] Imm AR 773, [54] (Burnton J) and E. Berry, 'The Deportation of "Virtual National" Offenders: The Impact of the ECHR and EU law' (2009) 23 JIANL 11.
} 
deportation' ${ }^{109}$ Under parliamentary pressure, however, the UK Government pulled back from this position, issuing regulations which prevent the Home Secretary's power to deport foreign prisoners at the end of their sentence from applying to Irish citizens. ${ }^{110}$ The Home Secretary is still able to order the deportation of an Irish citizen if this is considered to be necessary in the public interest. ${ }^{111}$ Under Irish law, by contrast, UK citizens are explicitly exempt from deportation in any circumstances, illustrating the ongoing divergences from reciprocity between the CTA jurisdictions. ${ }^{112}$

Perhaps even more problematically, the Bill's deportation provisions do not take account of the special position of Irish citizens who are from Northern Ireland. ${ }^{113}$ It describes a general power to deport Irish citizens, but does not consider the status of individuals who form part of the 'people of Northern Ireland' and exercise their GFA 'birthright' by choosing to identify as Irish alone. As we have already seen in the DeSouza litigation, the Home Office is insistent that such individuals are automatically UK citizens, whether they choose to identify as such or not. ${ }^{114}$ The hope underpinning the Bill, as drafted, seemed to be that the courts would resolve this dispute in the Home Office's favour. Whether they do so or not, the UK Government faced amendments in Committee which aimed to explicitly protect Irish citizens from Northern Ireland. To see these off, the Immigration Minister was obliged to provide assurances that, given 'the citizenship provisions in the Belfast agreement, we would consider any case extremely carefully and not seek to deport a person from Northern Ireland who is solely an Irish citizen' ${ }^{115}$ In summary, this new legislation takes some steps to give effect to the rights to enter and reside associated with the CTA, but it does not take express account of Northern Ireland's unique arrangements, and might in some circumstances facilitate

\footnotetext{
${ }^{109}$ L. Byrne, MP, HC Debs, vol. 457, col. 4WS (19 February 2007).

110 UK Borders Act 2007 (UK), s.32, as amended by The Immigration, Nationality and Asylum (EU Exit) Regulations 2019 (SI 2019/745) (UK), Reg. 17.

${ }^{111}$ Immigration and Social Security Co-ordination (EU Withdrawal) Bill 2019 (UK), cl.2(3)(a).

112 See the Immigration Act 1999 (Ireland), s.3. See also S. de Mars, et al., n 37, p.78.

${ }^{113}$ See S. de Mars, C. Murray, A. O'Donoghue and B. Warwick, 'Evidence to the Public Bill Committee on the Immigration and Social Security Co-ordination (EU Withdrawal) Bill 2019' (4 February 2019) para.7. https://publications.parliament.uk/pa/cm201719/cmpublic/Immigration/memo/ISSB02.pdf See also B. Ryan, 'Written Evidence to the Immigration and Social Security Co-ordination (EU Withdrawal) Public Bill Committee' (11 February 2019) A.11. Available at: https://publications.parliament.uk/pa/cm201719/cmpublic/Immigration/memo/ISSB05.pdf. Last accessed 30 June 2019.

${ }^{114}$ See above, $\mathrm{n} 80$.

115 Public Bill Committee, Immigration and Social Security Coordination (EU Withdrawal) Bill (Fifth sitting) (26 February 2019) col.175 (Caroline Noakes, MP).
} 
deportation of Irish citizens from the UK, especially as they will no longer enjoy the EU law's protections.

\section{The UK-Ireland Convention on Social Security}

If a particular dimension of the operation of CTA-related 'equal treatment' rights has been allbut completely usurped by EU mechanisms, it is the coordination of social security benefits between Member States. To support free movement of EU citizens, the Member States have all agreed to make many social security benefits portable; accumulations travel with EU citizens to different Member States, as a lack of portability would discourage anyone from exercising free movement. ${ }^{116}$ Social security coordination is therefore an activity which is often associated with the CTA, but which currently operates largely under the auspices of EU law.

That said, the association is deep and more organised than other aspects of the CTA. Between 1960 and 1971 Ireland and the UK concluded a series of agreements on aspects of social security (consolidated into a Convention on Social Security in $2004^{117}$ ). These bilateral arrangements do not, however, provide for more intense coordination between the UK and Ireland than the EU social security coordination regime. Instead, they provide for an extended zone of application. Notwithstanding the UK and Ireland's shared EU membership, the 2004 Convention was necessary to extend social security cooperation to cover the Crown Dependencies (and to cover their citizens in Ireland and the UK), which were also part of the CTA but outside the ambit of EU law. ${ }^{118}$ The effects of these developments can be seen in UK unemployment benefits, which count residence in any part of the CTA towards their 'habitually resident' requirement. ${ }^{119}$

With the then-presumptive Brexit date of 29 March 2019 looming, the UK and Ireland had to confront the extent to which their bilateral social security coordination rested on EU

\footnotetext{
116 See above, n 67.

${ }^{117}$ Convention on Social Security between the Government of the United Kingdom of Great Britain and Northern Ireland and the Government of Ireland, with Exchange of Notes (14 December 2004), (2007) Cm 7277.

${ }^{118}$ European Union Committee, Scrutiny of International Agreements: Treaties considered on 5 March 2019 (6 March 2019) HL 306, para.7.

119 See, for example, the Jobseeker's Allowance (Habitual Residence) Amendment Regulations 2013 (SI 2013/3196) (UK), Regulation 2, amending the Jobseeker's Allowance Regulations 1996 (SI 1996/207) (UK), Regulation 85A.
} 
law, and agreed a new Convention on Social Security. ${ }^{120}$ The House of Lords European Union Committee summarise the effect of this agreement:

[I]t seeks to roll over certain rights hitherto enjoyed by UK and Irish citizens in respect of each other's countries under various provisions of EU law ... that support "free movement", while limiting the enjoyment of those rights (so far as the UK is concerned) to Irish citizens. ${ }^{121}$

In Ireland, this Agreement was rapidly reflected in primary legislation scheduled to enter into force upon Brexit. ${ }^{122}$ The oversight of the specialist European Union Committee notwithstanding, this Agreement received little attention in UK Parliament, paralysed as it was by Theresa May's efforts to secure the ratification of the UK-EU Withdrawal Agreement. It was ratified without debate, and quietly actioned by Order in Council, ${ }^{123}$ separating Irish citizens using the CTA from the arrangements for other EU citizens being finalised under the Immigration and Social Security Co-ordination (EU Withdrawal) Bill. The fact that the UK and Ireland concluded this specific new agreement prompted the European Union Committee to wonder whether it needed to be supplemented by further legislation or additional international agreements in order to replicate other aspects of EU law which the CTA relies upon. It also cautioned that it 'is unclear ... whether a series of patchwork CTA agreements will provide the assurances that are needed on such a sensitive matter' ${ }^{124}$ The stage, therefore, appeared set for potential further dramatic CTA developments.

\section{The CTA Memorandum of Understanding}

For all of this preparatory work, the subsequent conclusion of the CTA MoU on 8 May 2019 would appear to be something of an anti-climax. The MoU was not intended to recast the CTA, but rather 'reaffirms the arrangement ... in relation to the Common Travel Area ... and the associated reciprocal rights and privileges enjoyed by British and Irish citizens in each

\footnotetext{
${ }^{120}$ Convention on Social Security, above $\mathrm{n} 3$.

${ }^{121}$ European Union Committee, n 118, para.2.

122 Withdrawal of the United Kingdom from the European Union (Consequential Provisions) Act 2019 (Ireland), ss.84-85.

${ }^{123}$ The Social Security (Ireland) Order 2019 (SI 2019/622) (UK).

${ }^{124}$ European Union Committee, n 118, para.11.
} 
other's state'. ${ }^{125}$ The subsequent provisions set out what the UK and Ireland understand the CTA to be, and the 'associated reciprocal rights and privileges' which accompany it. The MoU is drafted so as to make it clear that both parties agree that the relevant arrangements already exist, and are being recapitulated in the MoU because it is 'desirable to provide a contemporary articulation' of them. ${ }^{126}$ The associated rights recognised in the MoU are free movement; a right to reside; the right to work; the right to healthcare; the right to social protection (or social security); the right to social housing; the right to education; and the right to vote. This effectively mirrors the list of CTA-related rights previously identified by the UK Government, ${ }^{127}$ and could therefore be interpreted as containing no substantive extensions to the CTA.

Nonetheless, it is significant that both countries formally acknowledge that the CTA is not simply a free-movement zone, and explicitly tie the reciprocal rights for each other's citizens to the CTA. It is no longer an act of conflation to talk of these as being CTA rights. Both parties commit 'to ensuring that any necessary steps are taken to give effect to' the CTA rights, and identify in particular that domestic legal responses 'and further, more detailed, bilateral agreements' may be needed to protect these rights. ${ }^{128}$ The UK and Ireland further agree to hold annual meetings between senior officials regarding the MoU, presumably to consider any aspect of the functioning of the CTA-related rights in practice. ${ }^{129}$ These arrangements, however, remain diplomatic in nature; the MoU provides for no remedial mechanism if disagreements arise in one of these meetings, and expressly recognises that it 'is not of itself intended to create legally binding obligations'. ${ }^{130}$ Whereas the Convention on Social Security is a binding agreement under international law, the CTA MoU thus merely reflects the parties' 'common understanding' of the CTA's requirements. As such, the MoU required no ratification process before the UK Parliament, and was not subject to any debate amongst legislators. ${ }^{131}$

\footnotetext{
125 MoU, n 2, Para. 1 (emphasis added).

126 ibid., Para. 5.

127 See above, n 27.

128 MoU, n 2, Para. 14.

129 ibid., Para. 16.

130 ibid., Para. 17.

131 The UK Parliament does not routinely have to take positive steps to approve treaties; Constitutional Reform and Governance Act 2010 (UK), s.20(1). See J. Barrett, 'The United Kingdom and Parliamentary Scrutiny of Treaties: Recent Reforms' (2011) 60 ICLQ 225.
} 
The new CTA: Brexit-Proof?

We have seen three different forms of 'Brexit-proofing' to date: domestic legislative actions in the UK and Ireland, a binding international agreement and a bilateral political commitment. These efforts have been focused upon the CTA-related rights to reside and work, and to access social security protections. This has not been a process intended to strengthen rights, but one to provide an alternate legal basis to EU law. Although other CTA rights have yet to be addressed by bilateral arrangements at the time of writing, further activity is clearly envisaged. In January 2019, Ireland's Minister for Foreign Affairs informed the Dáil that '[b]ilateral arrangements as appropriate to each area of the CTA, will be concluded in due course and at the appropriate time' ${ }^{132}$ The implication is that a broad range of CTA measures will follow.

Ireland's Brexit legislation, moreover, permits the Health Minister to make orders 'to continue in being or carry out any reciprocal or other arrangements in relation to health services which were in operation between the State and the United Kingdom immediately before the withdrawal of the United Kingdom from membership of the European Union'. ${ }^{133}$ This suggests that arrangements have been made with the UK for steps to be taken following Brexit to protect reciprocal health care access for each other's citizens. Ministers confirmed that these provisions envisaged a no-deal scenario, when the rights of Irish citizens resident in the UK would not be covered by any overarching arrangements for settled EU citizens. ${ }^{134}$ Such statements, however, also highlight the patchwork of Ireland-specific and so-called EU 'settled status' measures which could apply to Irish residents of the UK after Brexit. The closed-room intergovernmental dealings to which these measures allude ${ }^{135}$ might be entirely in keeping with the history of the CTA, but they provide precious little reassurance to affected individuals. We must therefore evaluate whether this ongoing activity is sufficient to sustain the CTA-related rights after Brexit.

\section{Evaluating the CTA Reforms}

\footnotetext{
132 Simon Coveney, TD, Dáil Debates, Written Answer 5292/19 (5 February 2019).

${ }^{133}$ Withdrawal of the United Kingdom from the European Union (Consequential Provisions) Act 2019 (Ireland), s.4.

${ }^{134}$ S. Coveney, TD, Dáil Debates, vol.980, speech 377 (5 March 2019).

${ }^{135}$ As the Tánaiste informed the Dáil, '[w]e have a commitment that the UK will fulfil its side of the bargain and we will do ours, which is what we are trying to do in the Bill'; S. Coveney, TD, Dáil Debates, vol.980, speech 379 (5 March 2019).
} 


\section{Replacing the Irreplaceable?}

Under an orthodox account of the UK's dualist legal order, the UK's international agreements have no direct impact on rights and obligations within the UK's domestic jurisdictions; short of the UK Parliament incorporating treaty provisions into domestic law, they are not enforceable before domestic courts. ${ }^{136}$ Even then, it is not the treaty, but the statute which is being enforced. ${ }^{137} \mathrm{EU}$ law, however, is distinct in the UK's domestic legal system, because of its overarching principles of direct effect and supremacy. ${ }^{138}$ In order to join the EEC, the UK was obliged to make the provisions of the EEC legal order enforceable before domestic courts under certain conditions. ${ }^{139}$ It was also obliged to accept the Commission's enforcement action as an oversight mechanism, whereby the Commission can bring any Member State before the Court of Justice if they are failing to comply with either the letter or the spirit of EU law. ${ }^{140}$ On a constitutional level, Theresa May's administration conceived of Brexit as a means of ending these impositions: 'Whilst Parliament has remained sovereign throughout our membership of the EU, it has not always felt like that' ${ }^{141}$

Once Brexit stops the enforceable protections provided by the EU legal order applying within UK law, bilateral arrangements concluded between the UK and Ireland to cover Brexit's aftermath will inevitably be a poor substitute for EU law. ${ }^{142}$ This inevitability is reinforced by the fact that, as Charlotte O'Brien has highlighted, even though 'EU citizenship was always extremely limited in terms of the social protections it offered EU migrants', those limited citizenship rights have been implemented and applied in the UK in ways that has made them

\footnotetext{
${ }^{136}$ See $R$ v Secretary of State for the Home Department, ex parte Brind [1991] 1 AC 696, 718 (Lord Donaldson of Lymington) and 762-3 (Lord Ackner) and Miller v Secretary of State for Exiting the European Union [2017] UKSC 5; [2018] AC 61, [54]-[55] (Lord Neuberger). See also M. Hunt, Using Human Rights Law in English Courts (Hart, 1997) 7.

${ }^{137} R$ v Lyons [2002] UKHL 44; [2003] 1 AC 976, [27] (Lord Hoffmann).

138 See, for example, P. Craig and G. de Burca, EU Law: Text, Cases and Materials (OUP, 2015) Chs. 7 and 9.

${ }^{139}$ European Communities Act 1972, ss.2-3.

140 TFEU, Article 258.

${ }^{141}$ T. May, The United Kingdom's Exit from and New Partnership with the European Union (2017) Cmnd. 9417, para.2.1.

142 EU law on citizenship rights and social security is, admittedly, far from perfect and has been read in a limiting manner by the Court of Justice in recent years; see, for example, C. O'Brien, 'The ECJ sacrifices EU citizenship in vain: Commission v UK' (2017) 54 CML Rev 209 and S. Coutts, 'Citizens of Elsewhere, Everywhere and... Nowhere? Rethinking Union Citizenship in Light of Brexit' (2018) 69 Northern Ireland Legal Quarterly 231.
} 
even more difficult to access and exercise. ${ }^{143}$ For instance, UK courts have tended to interpret domestic implementing legislation of EU citizenship rights in narrow and conflicting ways. ${ }^{144}$ If we consider the future of the CTA post-Brexit, it is worrying that Charlotte O'Brien already finds that because the EU social security coordination regulation is 'complex, contradictory and incomplete', it has resulted in 'imaginative and exclusionary domestic interpretation' in the UK courts. ${ }^{145}$ There is no reason why UK courts would interpret legislation with its roots in that same coordinating Regulation, like the Order in Council that implements the Convention on Social Security, in a less exclusionary manner and after Brexit. And, even under the Withdrawal Agreement, the protections afforded by the oversight of the Commission and Court of Justice will lapse in the medium term.

The enforceability of affected rights will therefore inevitably diminish in practice. Indeed, in the broader context of settled-status rights for EU citizens, the EU has conceded that the protections afforded by its legal order cannot be replicated in a third country; the rights agreed under the Withdrawal Agreement will, if it is ratified, be enforced by the Commission in the EU (for UK citizens resident there) and, after a transition period, by a national body in the UK (for EU citizens resident in there). ${ }^{146}$ If an element of EU enforceability would be lost even with the ratification of the Withdrawal Agreement, bilateral arrangements between the UK and Ireland make for even less of a safeguard.

\section{The Nature of the new CTA Arrangements}

Ireland and the UK have used a range of approaches to securing the CTA after Brexit. The Convention on Social Security is a bilateral international treaty covering some CTA-related rights, enforceable by the state parties through arbitration. The first step of any disputes over

\footnotetext{
${ }^{143}$ C. O'Brien, Unity in Adversity: EU Citizenship, Social Justice and the Cautionary Tale of the UK (Hart, 2017), p.4. The book in general uncovers access and exercise difficulties caused by a combination of administrative barriers and erroneous first-tier immigration tribunal decisions, rooted in a lack of understanding of the relevant EU law.

${ }^{144}$ See, for a discussion of conflicting (and predominantly narrow) interpretations of the EU law requirements relating to sickness insurance for economically inactive migrants, S. de Mars, 'Economically inactive EU migrants and the United Kingdom's National Health Service: Unreasonable Burdens without Real Links?' (2014) 39 ELRev 770, 779-782.

145 O’Brien, n 143, 199.

146 Oversight of these arrangements involves a form of arbitration before a Joint Committee of UK and EU representatives, which cannot issue decisions and recommendations without mutual consent; Withdrawal Agreement, n 1, Article 166, para.3.
} 
the Convention is for the state parties to make 'all reasonable efforts' to resolve these through diplomatic channels, but arbitration is provided for as a follow-up option. ${ }^{147}$ The outcomes of arbitration will be 'binding on both parties' ${ }^{148}$ Whereas a violation of EU measures coordinating social security could be challenged before a UK or Irish court by affected private individuals, the Convention's arbitration provision is a tool employed at the state level, and various issues could dissuade one of the states from taking up an individual's complaints. On a purely diplomatic level, Ireland might be reluctant to commence arbitration against the UK as a larger trading partner unless significant violations were at issue. ${ }^{149}$

The overarching CTA MoU, by contrast, appears to be something short of a bilateral treaty. This is certainly the impression of civil society groups. As Brian Gormally, Director of the Northern-Ireland-based NGO the Committee for the Administration of Justice, observed before the Dáil; '[t]he problem with memoranda of understanding is that they are not, generally speaking, legally enforceable'. ${ }^{150}$ His Deputy, Daniel Holder, elaborated upon these concerns:

The Governments might agree to an administrative arrangement, but who knows who the next Prime Minister will be or make up the next government of Britain or what attitude it will take to those administrative arrangements? What we really need is an enforceable right. ${ }^{151}$

The name of an international agreement is not particularly significant in determining its nature; while Memoranda of Understanding are often non-binding agreements, if the parties had intended to make its terms enforceable, the CTA MoU could have provided the basis of bilateral obligations. ${ }^{152}$ However, the MoU itself leaves no room for interpretation, stressing

\footnotetext{
${ }^{147}$ Convention on Social Security, n 3, Article 62(2).

148 ibid., Article 62(3).

${ }^{149}$ For an account of how such power imbalances influence the use of international legal mechanisms, see $B$. Chimni, 'Third World Approaches to International Law: A Manifesto', in A. Anghie, B. Chimni, K. Mickelson and O. Okafor (eds.), The Third World and International Order: Law, Politics and Globalization (Brill, 2003) pp.47-73. 150 Joint Committee on Justice and Equality, 'Rights and Equality in the Context of Brexit: Discussion' (23 January 2019) p.26.

${ }^{151}$ Seanad Special Committee, n 30, p.11 (Daniel Holder).

152 Vienna Convention on the Law of Treaties (1969) 1155 UNTS 331, Art 2(1)(a).
} 
that it does not produce 'legally binding obligations'. ${ }^{153}$ The CTA MoU can also be contrasted with the UK's MoUs with countries such as Jordan and Algeria, regarding the deportation of individuals suspected of involvement in terrorism to their countries of origin. Each of these MoUs was intended to constitute 'an exceptionally strong political commitment' against the country of origin practicing torture, and their common understandings were undergirded by monitoring arrangements and specific rules for withdrawal. ${ }^{154}$ The CTA MoU, by contrast, provides for no such formal mechanisms, and so it becomes necessary to consider whether these new 'Brexit-proofing' CTA arrangements will be of any value in post-Brexit domestic litigation.

\section{Enforceability in Domestic Litigation}

Question marks remain over whether the new CTA arrangements can provide any meaningful assistance to individuals seeking to challenge alleged breaches of their terms before the domestic courts in the UK (or, indeed, Ireland). The first distinct issue is the value of the Convention on Social Security. As we have seen, this treaty has been brought into effect in the law of Ireland and the UK through domestic measures. In such circumstances, the UK Courts have long accepted the principle that statutes or statutory instruments designed to give effect to an international obligation 'are to be construed, if they are reasonably capable of bearing such a meaning, as intended to carry out the obligation' ${ }^{155}$ Irish claimants will thus be able to rely upon the Convention to secure their interests within UK social security law; indeed, the terms of the incorporating Order in Council explicitly provides that a range of social security legislation is 'modified to the extent required to give effect to the provisions contained in the Convention' ${ }^{156}$ In Ireland, the specific amendments to the Social Welfare Consolidation Act 2005 adopted to give effect to the Convention would similarly be interpreted in light of the Convention's provisions. ${ }^{157}$ The above concerns about UK policy

\footnotetext{
153 MoU, n 2, Article 17.

${ }^{154}$ See the UK Government's account of these measures before the Special Immigration Appeals Commission in Othman v Secretary of State for the Home Department (2007) SC/15/2005, [296].

155 Garland v British Rail Engineering Ltd [1983] 2 AC 751, 771 (Lord Diplock). See also Assange v Sweden [2012] UKSC 22; [2012] 2 AC 471, [122] (Lord Dyson).

156 The Social Security (Ireland) Order 2019 (SI 2019/622) (UK), Reg.2(1).

157 See, for example, discussion of the application of the Extradition (European Convention on The Suppression of Terrorism) Act 1987 (Ireland) in light of Ireland's international obligations in Finucane v McMahon [1990] 1 IR 165, 212-217 (Walsh J).
} 
makers limiting the effect of the relevant provisions aside, individuals will be able to directly rely on these domestic measures before domestic courts.

By contrast, the CTA MoU provides comparatively little support for any individual seeking to rely upon it to protect the CTA's 'reciprocal rights and privileges' in litigation in Ireland or the UK. ${ }^{158}$ Some recent decisions suggest that both countries' judges are becoming more receptive towards considering unincorporated treaties and other international arrangements, especially where individual rights are at issue, in the application of relevant domestic law. For Lord Kerr, such consideration is not a backdoor incorporation, it is merely allowing directly relevant standards to infuse our thinking about what the content of the domestic right should be'. ${ }^{159}$ In Ireland's Supreme Court Barrington J, dealing with the thenunincorporated European Convention on Human Rights, similarly opined that it may be helpful to an Irish court to look at the Convention when it is attempting to identify unspecified rights [under Ireland's Constitution]'. ${ }^{160}$ The UK House of Lords, moreover, relied upon the MoU concluded between the UK and Jordan to determine whether the UK had fulfilled its obligations under the Human Rights Act 1998 in the deportation of Abu Qatada. ${ }^{161}$ As such, the domestic courts could opt to treat the CTA MoU as something akin to an explanatory memorandum for domestic laws which, in practice, give effect to aspects of the CTA or which provide for special treatment of Irish citizens in UK law (or vice versa), such as the Immigration Bill currently before the UK Parliament. The problem remains, however, that domestic courts are not obliged to consider the MoU as an interpretative tool in the way that they are currently obliged to read any UK law implementing EU obligations in line with the original EU legislation. ${ }^{162}$ They may, moreover, be reluctant to place particular weight on the MoU on the

\footnotetext{
${ }^{158} \mathrm{MoU}, \mathrm{n} 2$, Art.2.

${ }^{159} R$ (SG) v Secretary of State for Work and Pensions [2015] UKSC 16; [2015] 1 WLR 1449, [261].

${ }^{160}$ Doyle v Commissioner of An Garda Síochána [1999] 1 IR 249, 268.

${ }^{161}$ See RB (Algeria) v Secretary of State for the Home Department [2009] UKHL 10; [2010] 2 AC 110. It is notable that after a challenge to these arrangements succeeded before the European Court of Human Rights in Othman $\checkmark$ United Kingdom (2012) 55 EHRR 1, the UK-Jordan MoU was replaced with a treaty; Treaty on Mutual Legal Assistance in Criminal Matters between the United Kingdom of Great Briton and Northern Ireland and the Hashemite Kingdom of Jordan Treaty Series No. 25 (2013) Cm 6861. For an overview of the saga of the litigation, and eventual deportation, see M. Garrod, 'Deportation of suspected terrorists with "real risk" of torture: The House of Lords decision in Abu Qatada' (2010) 73 MLR 631.

162 Under the duty of consistent interpretation (also known as 'indirect effect' or 'harmonious interpretation'), as developed by the Court of Justice in cases such as Case 14/83 Von Colson [1984] ECR I-01891, Case C-106/89 Marleasing [1990] ECR I-04135, and Joined Cases C-397/01 to C-403/01 Pfeiffer [2004] ECR I-08835.
} 
basis that they are dealing not with a formal treaty, but a mere understanding of the operation of the CTA.

The distinction between the MoU and a binding treaty also has specific enforcement consequences within the UK's devolution settlement. The Scottish, the Welsh and Northern Ireland institutions are all restricted in their legislative and executive competences through statutory obligations to respect the UK's commitments under international law. ${ }^{163}$ As a result, due to its competences with regard to social security, the Scottish Parliament had to pass legislation covering the Social Security Convention between Ireland and the UK. ${ }^{164}$ These obligations, however, do not apply to the non-binding terms of the CTA MoU. In the UK's increasingly complex jurisdictional landscape, restrictions upon supposedly reciprocal rights could therefore emerge from the devolved institutions. In this regard, it is worth remembering that some of the most egregious breaches of reciprocity prior to Ireland and the UK joining the EU came as a result of legislation passed by the Unionist-dominated Northern Ireland Parliament which functioned between 1922 and $1972 .{ }^{165}$

Finally, the Northern Ireland Human Rights Commission's Chief Commissioner has suggested that the new CTA MoU could form the basis of legitimate expectations for individuals, permitting them to institute judicial review challenges in the UK and Ireland if executive actors sought to take steps which diluted the reciprocal rights arrangements that it covers. ${ }^{166}$ The concept of legitimate expectations functions similarly in the administrative law of Ireland and the UK, permitting claimants who acted reasonably, in reliance on public authorities' promises or practices, to challenge attempts by the public authority to resile from that promise or practice. ${ }^{167}$ The aim of the courts is to ensure that public bodies 'deal straightforwardly and consistently with the public'. ${ }^{168}$ In the UK, however, the courts have been reluctant to treat international agreements as the basis for legitimate expectations.

\footnotetext{
${ }^{163}$ Scotland Act 1998, s.29 and ss.57-58, Government of Wales Act 2006, s.82 and the Northern Ireland Act 1998, s. 6 and s.26.

${ }^{164}$ Social Security (Ireland) (Further provision in respect of Scotland) Order 2019 (SSI 2019/93) (Scotland).

165 See, for example, the work permit system imposed under the Safeguarding of Employment (Northern Ireland) Act 1947 (NI); H. Patterson, 'In the Land of King Canute: The Influence of Border Unionism on Ulster Unionist Politics, 1945-63' (2006) 20 Contemporary British History 511, 521-524.

166 Seanad Special Committee, n 30, p.17 (Les Allamby).

167 See $R v$ North and East Devon Health Authority, ex parte Coughlan [2001] QB 213, [62] (Lord Woolf CJ) and Glencar Explorations v Mayo County Council [2002] 1 IR 84, 162-163 (Fennelly J).

${ }^{168}$ Abdi and Nadarajah v Secretary of State for the Home Department [2005] EWCA Civ 1363, [68] (Laws LJ).
} 
Laws $\amalg$, for one, was unequivocal in his rejection of this idea, asserting that the UK's domestic courts 'must not be seduced by humanitarian claims to a spurious acceptance of a false source of law' ${ }^{169}$ Even if the courts became willing to depart from this position, the CTA MoU is a different proposition from the unincorporated treaties Laws $\amalg$ had in mind. Its non-binding nature calls into question whether its terms could ever be treated as sufficiently committal to amount to a promise to affected individuals within the terms of legitimate expectations jurisprudence. ${ }^{170}$ Legitimate expectations doctrine is therefore highly unlikely to provide a basis for sustaining domestic law claims based upon the CTA.

\section{Coverage}

Beyond issues with enforcement, the legislative materials being developed to address the status of Irish citizens in the UK after Brexit do not replicate all of the rights they currently enjoyed as EU citizens. In particular, not all Irish citizens will enjoy the same rights to bring third-country spouses into the UK. Irish citizens who have moved into the UK under the CTA should be able to protect such rights under the EU settled status regime, if these provisions of the Withdrawal Agreement are ratified. As discussed above, however, Irish citizens who are part of the 'people of Northern Ireland' are excluded by the UK Government from the proposed settled-status measures for EU citizens. ${ }^{171}$ Irish citizens who were born in Northern Ireland will be, in this material regard, less protected, and more restricted in their ability to claim EU citizenship rights, than Irish citizens born elsewhere, even when both could be resident alongside each other in Northern Ireland. This proposition is all but impossible to square with the GFA's commitment to ensuring parity of esteem between people with British or Irish identities. ${ }^{172}$

If the Withdrawal Agreement is ratified, there are therefore distinct advantages, in terms of the substantive rights on offer and available enforcement mechanisms, for Irish citizens who can register for settled status to do so, rather than rely solely on CTA

${ }^{169} R$ (European Roma Rights Centre) v Immigration Officer at Prague Airport [2003] EWCA Civ 666 [2004] QB 811, [100]. See S. Patel, 'Founding Legitimate Expectations on Unincorporated Treaties' (2010) 15 Judicial Review $74,76$.

${ }^{170}$ See $R$ (Bancoult) v Secretary of State for Foreign and Commonwealth Affairs (No. 2) [2008] UKHL 61; [2009] 1 AC 453, [62].

${ }^{171}$ See above, $\mathrm{n} 77$.

172 See above, $n$ 84. See also K. Hayward and C. Mitchell, 'Discourses of Equality in Post-Agreement Northern Ireland' (2003) 9 Contemporary Politics 293, 296-297. 
mechanisms. If, however, the Withdrawal Agreement is not ratified, there is currently only a unilateral UK Government pledge that some settled status arrangements will be provided for EU citizens resident in the UK during a relevant qualifying period. ${ }^{173}$ Should this pledge be subject to legislation, it might well be shorn of the protections provided in the Withdrawal Agreement. First, there would be no obligation upon the UK to set up an independent monitor on the application of settled status and, second, those benefiting from settled status would not be able to rely on Court of Justice oversight of domestic court decisions during the first eight years of the scheme's operation. ${ }^{174}$ In those circumstances, the settled-status arrangements would exist at the whim of the UK Parliament, much as most of the CTA arrangements have done to date. This hardly amounts to meaningful 'Brexit-proofing' of the status of Irish nationals in the UK.

\section{Flattering to Deceive}

Since the end of 2018, UK Government's misfiring efforts to achieve Brexit have played havoc with the choreography of CTA developments. Standard international relations might have created the expectation of a progression from the overarching Withdrawal Agreement's permission of ongoing bilateral relations between Ireland, as a continuing EU-Member State, and the UK, as a withdrawing state, to the conclusion of bilateral terms, to their implementation in domestic legislation. Instead, under the pressures of Brexit, this process has become bizarrely inverted. The Immigration and Social Security Co-ordination (EU Withdrawal) Bill began its passage through the UK Parliament in a desperate effort by the UK Government to have the necessary pieces of domestic law in place for the 29 March 2019 deadline (the UK's putative "exit day"). Only some months later did the UK and Ireland conclude bilateral arrangements, binding only with regard to social security, whereas the conclusion of the Withdrawal Agreement, which formally permitted these arrangements, now looks a more distant prospect than ever.

\footnotetext{
173 Differences are already emerging between the unilateral no-deal scheme and the terms of the Withdrawal Agreement. Whereas the Withdrawal Agreement specifies a deadline of June 2021 for settled-status applications, in the event of no deal the UK Government will operate a December 2020 deadline; see M. MacDonald, Briefing Paper 8584: EU Settlement Scheme (House of Commons Library, 2019) p.3.

${ }^{174}$ Withdrawal Agreement, n 1, Articles 158-159.
} 
If this process has been tortuous for the UK Government, it has scarcely been easier for their Irish counterparts, who have had to balance the demands of reaching a bilateral accommodation with the UK with ensuring that any such arrangements are accepted by the EU. For Ireland, therefore, it would have been preferable for CTA arrangements to have been concluded after the Withdrawal Agreement. The responsibility for the delay in the conclusion of the CTA MoU, and its non-binding nature, cannot be laid solely at the UK's door. They Ireland's need to be seen to be part of a common European front on Brexit, rather than cutting special deals with the UK, and its desire to allow every opportunity for Westminster to accept the Agreement. The last minute scramble to sign the CTA MoU only took place when all hope for Westminster's backing of the Withdrawal Agreement was lost. Both countries' perceptions of the CTA have therefore diverged. For the UK, it remains a bilateral arrangement. For Ireland, it is an arrangement which must be accommodated within the country's EU commitments.

Perhaps the topsy-turvy nature of these developments was all too predictable, given the inherently peculiar nature of the CTA arrangements, which have persisted, excepting a hiatus during the Second World War and its aftermath, for nearly a century without clear formulation. And at least, when questions are asked about the nature of the CTA, there is now some level of clarity as to what the Irish and UK Governments understand it to involve. Or perhaps that should be, at most. The CTA MoU does not, indeed cannot, prevent the ongoing struggle over the openness of the Irish border after Brexit. An agreement to facilitate freedom of movement of persons between the UK and Ireland will not, of itself, keep the land border in Ireland all-but invisible for private purposes. As other contributors to the debate have made clear, this could only be achieved with the addition of an agreement between the UK and EU which covers issues such as the movement of goods between Ireland and the UK. ${ }^{175}$ More than that, as we have illustrated, the MoU does not bring with it the same legal architecture provided by EU law. Without such structures, it will be difficult if not impossible for individuals to rely on the supposed CTA rights in legal disputes.

As a result, the CTA MoU will ultimately do little to diffuse the tensions in UK-Ireland relations generated by Brexit or to prevent the CTA's provisions being eroded in the future. The MoU might even, in the best traditions of Brexit, come to be seen as trying to have its

\footnotetext{
${ }^{175}$ See K. Hayward, 'The Pivotal Position of the Irish Border in the UK's Withdrawal from the European Union' (2018) 22 Space and Policy 238, 245-252 and Schiek, n 41, pp.389-390.
} 
cake and eat it too. The two governments have prioritised preserving the flexibility of the CTA arrangements, whilst also giving clarity to those affected. Without legal protection, however, the clarity is illusory, and now that the MoU has formalised the content of the CTA, there is less chance of new rights becoming associated with it over time, as they have over the last century. Even this Brexit consolation prize - let's call it a set of steak knives - might well be blunt. 